\title{
Steelpan, Caribbean Identity and Culturally Relevant Adult Programs
}

\author{
Jean Walrond \\ University of Alberta \\ jwalrond@ualberta.ca
}

\begin{abstract}
The steelpan, ${ }^{1}$ a Caribbean percussion instrument forged out of resistance and rebellion, was introduced to Edmonton in the 1960s. Over the years, Caribbean heritage students have taken it to play for the school's "Cultural Days" to let others experience some aspects of their culture. In this article, I recount some of their experiences. More importantly, like them I recognize its importance to their cultural and social development and assert that this instrument, which is germane to Caribbean people, can be incorporated into culturally relevant adult education programs for people of Caribbean heritage who are living in Canada. I conclude that because education had been a problematic issue for people of Caribbean heritage in Canada, frameworks that are trustworthy will have to ground any culturally relevant adult education programs. Throughout this article pseudonyms are used to maintain the research participants' identities.
\end{abstract}

\section{Introduction}

When I first tried [playing the steelpan in school] I was in Grade 5. I did not know how to play it but my dad just said to take it [to school] and just hit the notes and [to] have fun with it. They [the students and teacher] were just excited and they just came and wanted to know if I was actually faking it. But you know they were all pretty excited. They all wanted to try it. The second time I took it to school I was in Grade 8 and then again in Grade 10. I was in one of those band classes [where] on a certain day of the month we had "bring your own instrument from a different culture" and just play it. So we would just play it. (Anna, Focus Group Interview, July 3, 2005)

In this excerpt from our conversation, Anna recalls her experience when she introduced the steelpan to her teachers and peers at school. Assumedly, she must have been very nervous, apprehensive, and fearful about doing this recital. But, I wonder if she gave any thought to the notion that this opportunity to perform her music was indeed a "tokenist gesture" (Gillborn, 2004, p. 36). In Grade 5, no one in the class was familiar with the steelpan (Anna, personal communication, 2005). Thus there was the obvious exocitising reaction akin to "superficial multiculturalism" (Gillborn, 2004. p. 36). The invitation to include her musical culture with the formal music curriculum is extended three years later and, finally, two years after the second appearance. She states that those were special "musical culture days" when the steelpan was allowed to be brought out. Another participant expressed her sentiments about Culture Day as follows:

Journal of Contemporary Issues in Education, 2007, 2(2), pp. 22-39.

ISSN 1718-4770 (c) 2007 University of Alberta

http://ejournals.library.ualberta.ca/index.php/JCIE 
It was Culture Day at school and we also had a cultural project at the same time. I was very nervous in the beginning before started this project. I would try something and I would say, "Forget it."... I showed them a video about Panorama ${ }^{2}$ and they said, "Wow!" I played the steelpan for Culture Day. Thank God, I remembered something!

(Theresa, Focus Group Interview, July 3, 2005)

These introductory statements are the most poignant parts of the focus group conversation I had with the six female members of Edmonton's TrinCan Steel Orchestra. They set the tone for my article as they graphically demonstrate pride in identity and cultural heritage. Even though Anna did not know how to play the instrument, she knew it was special to her culture and wished to share it with her classmates. Her vignette tells us that she vividly remembers only three instances throughout her public schooling when she took this instrument to school.

Cultural absenteeism, at school, is an experience that is not unique to Anna and Theresa. I have heard similar stories during the course of my conversations with Canadian youths of Caribbean ethnicity (Walrond-Patterson, 1999). Critics of this type of multicultural education identify Anna's experience as an attempt to appease minority students and their communities while still managing to keep the official traditional curriculum in place (Gillborn, 2004). As Green (1978) states, these types of incidents only contribute to "malefic generosity," and hence are of concern to those who support equality rights and social justice. How have these youths been served in their attempts to self-actualize during their schooling?

Anna and Theresa's stories highlight the reasons for my research among Caribbean Canadian families about their educational needs for social, cultural, political, and economic development. Education of this nature becomes problematic when we recognize contemporary education in terms of global social development (Kachur, 1999). Their stories demonstrate that from the perspective of the child a pedagogy of fear attributable to "dysconscious racism" (King, 2004) is the teaching as practiced in the classroom. But these stories are even more compelling when the injustices they portray in youth school experiences foreshadow what awaits women of Caribbean ethnicity ${ }^{4}$ (Hall, 1995) as they embark on their aging trajectory in Canada. The transnational experiences of women of Caribbean ethnicity imposes upon them racialized and gendered diasporic identities (Crawford, 2003) as a result of living in the "third space" (Wang, 2004) of "home"/Caribbean and "home"/Canada. How is our community and society going to assist these women with living productively as they move through the different stages of life and concomitantly straddle this third space?

Stand-alone programs such as those that incorporate adult literacy with good fitness practices already exist in several first world communities (Hudson River Centre for Program Development, 1993). While adult education classes are available to many and society is being acculturated to the benefits of life-long learning, it is predominantly Anglo-Western-Europeans who seem to take advantage of these opportunities (Guy, 1999). Cultural dissonance between home and school may be a determinant factor in how adults of Caribbean heritage perceive and access adult education (Guy, 1999). As well, literacy programs may not be appropriate as many from the Caribbean may not need these. The social justice issue for these women of Caribbean heritage will be their exclusion from activities that are necessary to sustain a quality of life that first world countries such as Canada excel at and are proud to acclaim. This paper examines the discourse of women who play the steelpan to address social justice issues. It also supports the 
need to incorporate "culturally relevant" (Ladson-Billings, 1994, p. 87) materials into adult education for Caribbean heritage women living in Canada.

\section{Background to the Study}

\section{A Very Brief History of the Steelpan}

Many people of Caribbean heritage claim African drums and the Tassa drums of India as the basis of their musical heritage (Johnston, 1998). The steelpan, a percussion instrument, was invented on the twin island country of Trinidad and Tobago in the 1930s by youth who, having been denied the opportunity to play their ancestral drums turned to empty oil drums to satisfy a musical yearning. Many stories abound about the racialized laws that were imposed by slave owners and colonial masters to prevent the beating of the drum. They believed these were instruments that could be used to relay messages if the enslaved wished to plot an insurrection.

The first rudimentary percussion instruments were played by poor inner city youths. Over the years, the steelpan has improved in versatility and stature and is now touted as the only percussion instrument to be invented in the $20^{\text {th }}$ century. Today, it is included in the musical programmes of most Trinidad and Tobago schools and its importance is recognized within the Caribbean diaspora around the world.

\section{Storytelling}

Critical race theory uses vignettes or stories similar to the educational experiences of these females of Caribbean heritage to foreground social justice issues. The critical race theoretical approach undertaken in this study allows for the use of concepts and associated notions of whiteness and blackness to frame an argument against social justice issues. In this case, whiteness is associated with "school achievement," "middle classness," "maleness," "beauty," and "intelligence," while blackness is associated with the marginalized categories of "gangs," "welfare recipients," "basketball players," and "the underclass" (Ladson-Billings, 2004, p. 51). As well, critical race theory acknowledges racism as a normalized activity in society. In addition, it seeks to story the experiences of minority groups to analyze racial presuppositions. Lastly, it critiques liberalism's views of incrementalism as the only process for social change. Critical race theorists argue that Whites are usually the ones with the social, political, and cultural capital to be able to take advantage of, and thus benefit most from, any policies that are set up to redress historical injustices.

Another aspect of this paper is its emphasis on the steelpan stories of females. Women were always part of social justice struggles in the Caribbean. Though very little has been written about this, Reddock (1994) has now set forth in her text "Women, labour \& politics in Trinidad \& Tobago: A history," examples of their activities that date as far back as the early $20^{\text {th }}$ century. She acknowledges progressive women such as Audrey Jeffers, my aunt Clementine Howard, and other members of the Coterie of Social Workers, who worked tirelessly for universal suffrage, supported youth lunch programs, provided housing and activities for single or widowed working "ladies," and actively supported the development of a Caribbean culture. Collins (2000) captures this energy as she theorizes: "Black feminist thought demonstrates Black women's emerging power as agents" (p. 553) who confront race, gender, and class oppression, as an emerging power and self-defined and self-reliant agents of knowledge. In this context, Ladson-Billings 
(1996) advocates a womanist tradition to multicultural education as one perspective that creates dialogical spaces to address social justice issues which occur at all levels of education.

I acknowledge my Caribbean heritage and specifically that of the twin island country of Trinidad and Tobago, the land of Carnival, Calypso, and the steelband (a band of several steelpans, namely tenor, bass, guitar, and cello). ,I have researched the immigrant's use of dress, as depicted in street theatre events such as Carnival, to negotiate identity in a Diaspora. I also acknowledge my close relationship with Canadian schooling as I have educated two children in systems across Canada.

I choose to interview these females in the TrinCan Steel Orchestra because of the unique relationship females historically have had with steelpan instruments and, moreover, to demonstrate how involvement in steelpan playing has helped Caribbean-Canadian women in the diaspora to use aspects of their cultural identity and cultural public pedagogy to negotiate education to make meaning of their lives within their schools and the dominant society in Edmonton. I am not trying to suggest, with this article, that all women from the Caribbean will wish to "beat the pan". I am using it to highlight the cultural ideals which people from the Caribbean value. In seeking to make a case for culturally relevant education for adult females from the Caribbean, this article focuses on female school resistance andsteelpan playing as a developed female activity and cultural pedagogy. This article first looks at steelpan as an instrument of social justice revelation and resistance (Hall, 1993). Secondly, it explores how some female youths in the Caribbean community, once again purposefully, use the instrument as critical cultural pedagogy for social resistance, social action, and social reconstruction.

\section{Students' Educational Experiences in a Diverse Classroom}

Many articles address the problems of resistance and cultural inversion (Solomon, 1992); streaming and labeling (James \& Brathwaite, 1996); truancy and lack of respect for authority (McLaren, 2003); Black youth alienation from the public schools (Hopkins, 1997); "class, context and the complex intersections of masculinity and ethnicity," ( Sewell, 2004, p. 103) and minority school-culture challenges (Ogbu, 1991, 1992) that are part of the legacy of Black youths or Black male youths in formal White school structures. However, it is worthwhile to isolate Black females. Youdell (2004) writes about African Caribbean girls' "triple subordination - along the axes of race, class and gender" and that their resistances to school "were seen to be located within an accommodation of schooling" (pp. 84-85). Bhatti (2004) also writes about these students" attitude of "resistance within accommodation" behaviour, but she also states that they were "able to use school in a way that was "instrumental, that is knowledge is not valued for its own sake but as a means to an end, that of gaining qualifications" (p. 139).

The educators at the schools Anna and Theresa attended must have felt they were making positive strides in education towards national citizenship by having multicultural days as a minimal part of the curriculum. Sleeter's (1996) study of similar school situations found that these efforts did not embody a spirit of community because the "schools had little (if any) connection with community-based movements that aim toward equality and social justice" (p. 240). She claims that in many educational systems, educators were prone to conceptualizing multicultural education as therapy to cure individuals of prejudice and stereotyping, as a teaching technique, and as academic discourse (Sleeter, 1996). Is this type of education satisfactory for students of Caribbean heritage in multicultural countries such as Canada? Benmayor (2002) articulates that "claiming cultural citizenship means affirming the right . . . to receive quality 
education [and] ... to be valued for the cultural "assets"' (pp. 97-98) one brings to schooling in the $21^{\text {st }}$ century. Thus, how can this be assured?

\section{Why Frame This As A Social Justice Issue?}

Young (2000) writes that in well-intentioned liberal societies social injustice is designated by a structural oppression which manifests itself as exploitation, marginalization, powerlessness, cultural imperialism, and violence. She says that the causes of social injustice are "embedded in unquestioned norms, habits, and symbols, in the assumptions underlying institutional rules and the collective consequences of following those rules" (p. 36). Young (2000) defines this dual occurrence of lack of formal cultural representation with the typifying of culture as belonging to the "other" as cultural imperialism. She says:

To experience cultural imperialism means to experience how the dominant meanings of asociety render the particular perspective of one's own group invisible at the same time as they stereotype one's group and mark it as the Other (p. 44).

Young (2000) also cites Du Bois to contend that this sense of "double consciousness," or always having to see ourselves in reference to the other, results in the individual being both invisible and marked simultaneously. Invisibility occurs because the dominant groups fail to recognize their cultural expressions as ". . . [one] perspective" (p. 46) among many, and have little or marginalized space for the cultural expressions of other perspectives in their paradigm. In spite of the cultural diversity rhetoric, nation states such as Canada continue to support structures which propagate their dominant culture (Guy, 1999; Naylor, 1998), leading Young among others, to conclude that "[t]his, ... is the injustice of cultural imperialism" (p. 46).

\section{Cultural Identity and A Pedagogy of Resistance}

In educational contexts such as schools and colleges, the political effects of identity are most apparent to those whose identities fall outside the sphere of normalized cultural identities (Hall, 1993, 1996a, 1996b). Giroux (1999) acknowledges the power and structural characteristic of culture in defining it as "the production and legitimation of particular ways of life transmitted in schools through the overt and hidden curricula so as to legitimate the cultural capital of dominant groups while marginalizing the voices of the subaltern" (p. 1). Giroux, Apple (2004), and McLaren (2003), amongst others, acknowledge that from the perspective of social theory, politics relates to everyday life because of the control its pedagogical practices, relations, and discourses have on the everyday lives of individuals. He makes this claim on the basis that "social theory ... expands the meaning of the political by being self-conscious about the way pedagogy works through its own cultural practices in order to legitimate its own motivating questions, secure particular modes of authority" (Giroux, 1999, p. 1), and reinforce particular institutions and structures. In Giroux's (1999) analysis of one of Gramsci's works, he further deduces that "the politics of culture was inseparable from a politics that provided the pedagogical conditions for educators to think critically about how knowledge is produced, taken up, and transformed as a force for social change and collective struggle" (p. 15).

Sleeter (2002) writes: "Knowledge in democratic societies generally is not produced through a conspiracy, but rather by actors within shared spaces of power, drawing on shared 
funds of knowledge and experiences" (p. 9). Thus, within schools, how can students work within civil society to bring about the changes they wish? Sometimes, even if teachers wish to practice a critical multicultural pedagogy, a cultural pedagogy, a culturally relevant pedagogy, or an anti-racist pedagogy, they may not be successful. Many teachers speak of color-blindness. Sleeter (2004) also claims that many teachers, because of white guilt about racism, may hold negative assumptions about programs or the attitude that they already "know all about" multicultural education, do not invest the time necessary to acquire the skills needed to teach in multicultural classes. Sleeter summarizes, "for teachers of color it should help to politicize and develop what they know from life experience and to translate their commitments into emancipatory actions in schools" (p. 176). This is problematic as some school jurisdictions do not have the critical mass of Black teachers to make this suggestion viable. First, not every Black teacher views her or himself as a role model for Black students. Secondly, many may feel that they do not have the empowering opportunities for doing advocacy and emancipatory work within schools. What are the students to do? Faced with these dilemmas, students resist in ways that are within their scope. Many choose to remain in school and be instrumental, while others choose to underperform and drop out. As Mahoney (2005) aptly phrased, "in the case of Toronto, . . . administrators have long noticed that higher numbers of African-Canadians underperform and drop out of school" (p. 18).

Culturally relevant pedagogy engages students as they explore empowering opportunities for their educational, emotional, social, political, and cultural development, as well as critical sociopolitical consciousness (Ladson-Billings, 1994; Grant \& Ladson-Billings, 1997). Similarly, (Giroux, 1999) suggests that cultural pedagogy views schools as sites of struggle which allow students the opportunity to understand the relevance of civil society as a public vehicle for using "their moral and political energies as acts of resistance and struggle" (p. 15). In this respect, Giroux (1999), Kellner (1995), Lovelace (1998), and others, cite instances where art, performance, and crafts are used to affirm Black or subaltern pride, to construct and reconstruct identity, and as a response to racism and other social injustices.

\section{Making the Case for Culturally Relevant Adult Education}

Though Black females are more adept at concealing their feelings, and approaching school very instrumentally, their frustration with the system nevertheless exists. In school systems where school attendance is somewhat mandatory, black females show their dissatisfaction with education by either being instrumental or dropping out. Clearly, if the youth's school reality is a bi-cultural experience in which they participate reluctantly, it is inconceivable to expect a similar situation to occur with life long learning and adults who are not mandated to attend.

At this point, my theoretical underpinnings suggest that female students of Caribbean heritage use music from their cultural background to define subjective positions and as metaphors of resistance during their schooling. Culturally relevant pedagogy suggests that elements such as Caribbean music, which make meaning in the lives of these youth, can provide relevancy to their education. Culturally relevant adult education for people of Caribbean heritage should integrate the ideas of culturally relevant pedagogy and practices of the female students. Programs of this nature may encourage Caribbean Canadian adults to pursue a practice of life long learning. 


\section{The Steelpan as a Cultural Medium: The Rhythmic Beat of Resistance}

The history of the steelband allows those who study the pans to reflect on the struggle of enslaved Africans during slavery and as freed people during colonialism. These struggles were economic, social and cultural, and their resistance was often expressed in their efforts to maintain their music and, when that failed, to replicate the African rhythms of their ancestors. The pans continue their appeal as an instrument of resistance even across the diaspora. It was introduced to Edmonton, Alberta to resist racism and once again, as pointed out in the stories of my five participants, it still functions in that role today. Although their formal schooling was not providing this education the panyard "was fulfilling this need and creating a valuable epistemological terrain upon which to develop modes of critique that illuminates the interaction of the social and the personal as well as of history and private experience" (Giroux, 2001, p. 35).

Thus, the steelpan, $20^{\text {th }}$ century's only percussion instrument invention, was "born out of frustration and social ostracism" (Jones, 1982, p. 5). During slavery, when the West Indies was the world's major producer of sugar, the original cultural activities: religion, language and traditional drum beating, were curtailed and, in most cases, prohibited activities for enslaved Africans. Their Aboriginal language was thus forbidden, religion was a clandestine activity, and African drumming was only allowed as a reward or treat during the plantocracy's festive activities. Thus, "[i]n the early part of the year the burning of the [sugar]canes before reaping was celebrated with the beating of the drums and a candlelight procession" (p. 8). After emancipation in 1838, the prohibition of drum beating was strictly enforced although by now there were two groups, the East Indian indentured labourers and the freed Africans, whose cultural activity included drumming. With a prohibition on traditional drumming in place, Trinidadians turned to many other implements to recreate the African drumming sound, but with little success. Prior to World War II, the steelpan was invented in John-John, Trinidad where "the depressed, frustrated, under-privileged and poor people sweat out their drab and dull existence in the slums and poverty not of their own makings" (Jones, 1982, p. 12). They discovered that by tempering the face of oil drums with heat, and sinking it to a concave surface, they could produce chromatic scale musical notes on the raised sectors of that face (Jones, 1982; Sealey \& Malm, 1982; Mike Lancaster, personal conversation, October 20, 2001). As Johnson (1998) writes:

The development of pan is largely a story of the young men of Trinidad in the 1940s, ' $50 \mathrm{~s}$, and $60 \mathrm{~s}$ straining to create a melodic instrument out of a drum, labouring to acquire virtuosity of performance and composition with it. They began with rhymes, choruses for simple songs, then entire songs until, by the time of the 1952 music festival, they were attempting European art music (p. 63).

This statement can be a metaphor for the psychological struggle that existed among the steelpan men as they tried to climb the vertical ladder of social respectability. Their life stories mirror the story of the pan and also mirrors the journey of the people of Trinidad and Tobago, from slavery and colonialism, to independence. Johnson continues:

[Today] I too can recall pushing pans as a child when steelbands paraded on the streets for Carnival. It is a mark of belonging, an honour even, to be a part of one of the huge caravans that poured their rivers of music on the road. I too would have stood out starkly 
as a middle-class child amongst the more plebeian steel band supporters, and I never met the slightest hint of rejection (p. 63).

Thus, although Johnson writes of levels of female acceptance, the morality of the steelband women who accompanied the men was quite often questioned, as they were deemed to be promiscuous and free spirited. Alexander (1991) writes of Trinidad and Tobago's society, that "Attempts to manage sexuality through morality . . . are inextricably bound to colonial rule. In fact, the very identity and authority of the colonial project rested upon racialization and sexualization of morality" (p. 133) and, along those lines, "the valorization of the values and practices of 'Indigenous cultures"' (Narayan, U., 1997).

A visit to any Trinidad and Tobago pan $\operatorname{ard}^{5}$ today will show no evidence that, until the 1970s, women invariably did not play the steelpan ${ }^{6}$. As a youth on visits to my grandmother's home during Carnival, although I was always fascinated by the steelpans of 'Proud Rebels' Steel Orchestra which were housed in her yard, my sister and I were not allowed to go any where near those badjohns ${ }^{7}$. Even though my aunts (my father's sisters) worked with these youths to create a sense of community, my mother's Roman Catholic upbringing and social class aspirations did not permit us to indulge in that activity. So we stayed in-doors during our visits. My aunts had a better grasp of the emancipatory changes taking place in the country of Trinidad and Tobago just prior to its independence in 1962. They understood that political identity and cultural identity were concomitant aspirations, and also that as far as Trinidad and Tobago were concerned, the bedrock of our national culture included our steelpan. Today the steelpan is part of schools' musical curricula in Trinidad and Tobago and many women have chosen to play these instruments, not only in Trinidad, but within the diaspora (Albino-de Coteau, 2005).

\section{Charting our Course in the Society: The Strategy, the Knowledge}

In 2001, I conversed with Mike, our Caribbean cultural pedagogue who introduced steelpan, Calypso and Carnival to Edmonton, Alberta. Mike's idea to introduce the steelpan to Edmonton was an attempt to deal with the social injustice that was meted out to him in the workplace and in society. He wanted White people to look past his black masculinity and its associated essentialist "phallocentric framework" (Sewell, 2004). He shared this conversation:

In the workplace, too, we had some problems like that. It all sprung from race. . . She was working there and this is the plot they set up, for her to phone me and ask me if I want to go and have a drink with her. One thing I would like to say, I think is, actually when you've just come here, you're lonely, but I did not phone her - SHE CALLED ME. . ... So I said, yes. The next thing you know, she went and told all her workmates that I phoned her and asked her to go out. That was like committing a crime. They fired me! [Pause] . . . That's super-emotional. There are so many things I went through here. [Very long pause] (Mike Lancaster, Personal Communication, October 20, 2001)

Mike's use of the steelpan as an instrument of resistance and as an identity marker is more a common practice among males in the Canadian Caribbean community than it is for females. This is the case in spite of the fact that both males and females in the Caribbean play the steelpan and the females members of TrinCan overwhelmingly spoke about the bond they have with the steelpan. Trueba and Zou (1998) theorize, "as immigrants and ethnic groups 
reaffirm and redefine their identities in contrast with other groups as well as mainstream peoples, they seem to hold power, to control their destiny, and to succeed in their risky ventures as immigrants" (p. 1). The individuals in TrinCan Steel Orchestra identify Nigeria, Ghana, Trinidad and Tobago, or Canada as their heritage and they come together to perform in schools, parades, community functions, and social gatherings.

To address my research question, I use qualitative methodologies. These include my conversation with Mike, ethnographic visits to the panyard, in this case a community hall, a focus group conversation with the females, and my autoethnography. Situating the pannists in the world, or phenomenon of the pan, is foundational to this inquiry (Denzin and Lincoln, 2000; Fine, Weis, Weseen, \& Wong, 2000). During this process, the researcher transforms the participant's world into a series of "field notes, interviews, conversations, photographs, [and] recordings," (Denzin and Lincoln, 2000, p. 3) memos, and self-reflective diary entries. We witness in this authentic cultural story telling (Narayan and George, 2003), the coming to life of "personal text as critical intervention in social, political, and cultural life" (Jones, 2005, p. 763) to construct the grand resistance narrative of the steelpan and Caribbean people. Supported by Fine et al's (2000) assertion about acknowledgement, I, as a Caribbean community member, was able to gain unobtrusive entry into "safe places" (Fine et al, 2000; Ladson-Billings, 2000) of both the panyard and Mike's memory, to access their autoethnographic stories (Tedlock, 2005).

\section{Responsive Resistance}

Mike uses the steelpan as a resistance response and to centre him as an immigrant (Hall, 1996b). Similarly, the females in this article use it as resistance but also "as if they own the territory" (p. 114). They got involved with playing the steelpan by accident and by their own volition. Initially, they were not encouraged to do so by their parents but once the interest was shown they were encouraged to develop it. This is Anna's conversation with other group members about her initiation to the steelpan:

It was a kind of fluke. When my dad used to own a store, he had a pan in the back of it and I used to fool around with it. One day my Dad heard me playing the pan and he taught me a song. I learned it, I thought it was in two seconds. So, after that moment, I just started going with him to practice. I just hung around there.

[Stephanie] You were hooked.

[Anna] I was not really hooked, I was kind of forced.

[Teresa] He kind of expected it.

[Anna] Yes, and after that I was kind of hooked.

[Theresa] My parents went away and I was staying at my cousin's place and both of them played in the band so they were babysitting us. So we came by and my older sister, she remembers, we were fighting over the bass, right! We are learning, "Unchained Melody." So, my cousin would show me the first part and then my sister would go on and 
I would say, Okay, get off and I would come back on. And, Harry would say, Okay, you have got it. And I just stayed, I loved it!

[Judy] Well after seeing what you all were doing for years and years, I thought, oh well, this is kind of cool, to go traveling to places with these guys and the music is part of my culture. It is the type of music that I always enjoyed. So I said, I might as well start. But since they needed tenors, I did not have a choice as to what musical instrument I should play. So now I am okay with it. (Focus Group Interview, July 3, 2005)

All the girls stated that they look forward to coming out to practice and that a feeling of camaraderie and friendship exists among them. While their cultural heritages are as varied as Nigeria, Canada, Trinidad and Ghana, they all have close cultural ties to the steelpan. Some think that this is so because it is so similar to the drums. I observed this comradeship when I visited the panyard. There were special codes. For example, I saw others leaving notes and packages of candy on the pans of those who had not yet arrive. One of the females was also responsible for informing the others where they would be playing next. Thus, at the end of the session, they all lingered around after the leader said his final remarks. After he was finished speaking, she told the younger ones what they were expected to do next. It was then that she announced that I wanted to meet them for a focus group conversation. Harry had already told me that I would have to speak with this particular individual and she would get the girls together. I was impressed at the way they listened to her as she told them what I was there to do. Not surprisingly, at the appointed time they were all there. To me she just took control of the initiative and they all supported her.

In terms of seeing it as part of their culture, this is what some of them said:

I think we just use it to say; that it is part of our culture. You know what I mean. Because once you play it, you feel like you are a part of it. I have only been to Trinidad once, but there was so much stuff that I did not get to see, you know what I mean. But playing the pan makes you feel good about yourself. There are some things over there, like, when you hear Panorama tapes you want to go there. Yes, I think that it helps me, at least, to identify with a part of my culture that I do not really feel I know enough about. But, at least I can say, at least I can say, that I know something about it, you know what I mean. (Focus Group Interview, July 3, 2005)

Anna said the following:

The thing about me is that I have been around it ever since I was born, so it is just like second nature to me I guess. It is kind of like you learn to respect it. Because when I was younger it was not really a problem. But when I turned fifteen and sixteen and practice is Friday night. And you do not want to go and practice, I want to go out with my friends and so on. So hear me: I am going to quit the band. But then later on you come to realize that you know, it is also important to play. It is important to stay in and to do it because it is part of you. It is part of your culture and it is something you should really cherish. You know I have come to respect it more. (Focus Group Interview, July 3, 2005) 
Another respondent said:

Obviously people like Anna who has grown up at the panyard and all this is true. But for me even if everything in your life changes, pan is the number one thing. That is just the way it is, and so people say: Where is your pan! [laughter] But when you come together with someone, like the people that I am with and I say I am going to the "pan". Those persons have to understand. They have to get it because I am going there. We may not get here until eight but after that I am going to stay here with it. Some people do not understand. Because my mom thinks: Oh you do not like me, because it makes them mad. But we say just respect this one thing. You know what I mean. There are those days when we thought we could give up the pan but you can't. It is addictive because when you are away from it you say: Oh, I miss it. That is it, exactly. I feel so guilty. It is like so important to me. (Focus Group Interview, July 3, 2005)

From this exchange I understood how seriously the girls take their practice. It also points out that their family and friends have to understand that their steelband practice comes before all other socializing events.

[Anna] Well when you think about the history of pan, to play pan it was almost like a rebellion, right, people used to get into lots of trouble so I think just continuing to play, continuing to keep it on is just keeping the pan alive, and keeping what they believed in alive, so, in a way, it definitely represents social justice because it is something that they did have to overcome in trying to maintain our culture.

[Jean] And do you all understand the ramifications of not being able to play the drums and so we resorted to the pan.

[Anna] Well, it is just that the authorities tried to take one thing away but they came up with another. So, it was someway of trying to find, some way maintain, what you had before and that is very good. Because, nobody should try to take any thing away from us, especially if it is something that we love.

[Anna] Nobody can destroy the things that sort of keep you going. You just transfer it to something else. My dad has a song. "The mind is . . the mind is the only thing that they cannot destroy when we are in the struggle," or something like that. (Focus group interview, July 3, 2005)

Here Anna is reflecting on the story of the steelpan. But, what does the future bring? I wanted to find out if the group felt that the steelpan should be used in adult education and Anna saw it as being used to educate others about Caribbean culture. The older White female in the group who got involved with the music when the community college offered it as a course in their "outreach" program felt that although "you have to practice your scales " (personal communication, July 3, 2005), it was fun because it was not too structured. She said, "You can give people another perspective that you do not have to have the theory to play music." (Michelle, Personal Communication, July 3, 2005) 
In terms of how the females are accepted by the community, they suggest the following:

[Anna] There are lots of females playing pan. They are doing everything. It does not really hold anymore that it is just a male thing, you know.

[Michelle] They do not say anything. Once you are playing very good they are just admiring. And quite often Anna will be playing all by herself. If we are doing something unique you will hear, I think they are good.

[So are you saying this about guys in the audience and stuff?]

[Angie] Especially when they think of the word 'sexy,' it is like WOW!

[Anna] I remember once there was this one guy many years ago, when I was young, he was just staring. He was just saying that it is good, it is good, you look good. I guess the older people still have that love. (Focus Group Interview, July 3, 2005)

Evidently the community loves the instrument, the females in the band, and the enjoyment they bring it's music to the community. They also shared that getting together to play builds a sense of community. The Indigenous way of playing is by "ear" and practice, so there is no need to be skilled in music theory. They play because they enjoy the music and "it is open to anyone who wants to come" (Judy, personal conversation, July 3, 2005). Because of the pedagogy involved in learning Indigenous types of music, the environment is very relaxed and apprenticing with a master is integral to learning. Individuals find that they work better and learn from each other in a cooperative way. Hence, the environment is usually not stressful, and laughter is essential, even if an incorrect note is played. I noticed this in my personal visit and Michelle confirmed it during the group's conversation.

And then there is Michelle again, again, I did not even do it and it is wrong. "What are you writing? [She finds it easier to write down the notes] Put your pencil down. I am having lots of fun. ... I think we should get him a t-shirt which says, one more time and then we will go.

[Anna] We should. It is always "one more time."

\section{Concluding Perspectives}

I have demonstrated that involvement in Caribbean music making and performance has helped these Caribbean Canadian and African Canadian women develop a sense of self and responsibility both within school and in society. I have also tried to show that these female players have heard the resistance stories and they took these with them to school. It is not surprising that the resistance story of the steelpan echoes through their sub-consciousness. They live out the metaphor that embodies the face of the old oil drum. Stretched, pounded and fired, it 
emerges to produce a rhythmic beat that personifies resistance. So, too, do the people in my article. In this article, I also try to demonstrate how learning the music of the steelpan engages adult learners in an activity that seems to focus on fun and enjoyment with low stress. It is also still very appealing to the community as evidenced by the stories the research participants have told. Peterson (1990) says adult education that emphasizes matters of community interest; whether these programs are cultural civic or vocational, are successful in African American communities. Although he recommends that an understanding of community needs is important for the provision of culturally relevant adult education, he supports "the need for an expanded dialogue on the role of education" (p. 85) in African diaspora communities. For example, since the education system has frequently used academic tracking of students of colour on the pretense of learning disability and cultural deficits, there is an element of mistrust with the education system that carries on through adulthood. Continued focus on literacy programs for adults fails to actually deal with the systemic problems that are inherent in the education of people such as those of Caribbean heritage. 


\section{References}

Albino-de Coteau, M. (2005). Women's contribution to the steelpan movement. Retrieved October 11, 2005, from http://www.panonthenet.com/woman/2005/Albino-deCoteau.htm

Alexander, M. J. (1991). Redrafting morality: The postcolonial state and the sexual offences bill of Trinidad and Tobago. In C. T. Mohanty, A. Russo, \& L. Torres, (Eds.), Third world women and the politics of feminism (pp. 133-152). Indianapolis: Indiana University Press.

Apple, M. (2004). Ideology and curriculum (3 ${ }^{\text {rd }}$ ed.). New York: RoutledgeFalmer.

Benmayor, R. (2002). Narrating cultural citizenship: Oral histories of first-generation college students of Mexican origin. Social Justice, 29(4), 96-121.

Bhatti, G. (2004). Good, bad and normal teachers: The experiences of South Asian children. In G. Ladson-Billings \& D. Gillborn (Eds.), The RoutledgeFalmer reader in multicultural education (pp. 139-162). New York: RoutledgeFalmer.

Crawford, C, (2004, March). African-Caribbean women, Diaspora and transnationality. Paper presented at a Graduate Students' Conference on Examination of Black Canada in a Changing National Context, Toronto, ON.

Collins, P. H. (1999). Black feminist thought in the matrix of domination. In C. Lemert (Ed.), Social theory: The multicultural and classic readings ( $2^{\text {nd }}$ ed., pp. 553-564). Boulder, CO: Westview Press.

Collins, P. H. (2000). Black feminist thought: Knowledge, consciousness and the politics of empowerment ( $2^{\text {nd }}$ ed.). New York: Routledge.

Denzin, N. K., \& Lincoln, Y. S. (2000). Introduction: The discipline and practice of qualitative research. In N. K. Denzin \& Y. S. Lincoln (Eds.), Handbook of qualitative research $\left(2^{\text {nd }}\right.$ ed., pp. 1-28). Thousand Oaks, CA: Sage.

Fine, M., Weis, L., Weseen, S., \& Wong, L. (2000). For whom? Qualitative research, representations, and social responsibilities. In N. K. Denzin, \& Y. S. Lincoln (Eds.), Handbook of qualitative research ( $2^{\text {nd }}$ ed., pp. 107-131). Thousand Oaks: Sage.

Gillborn, D. (2004). Anti-racism: From policy to praxis. In G. Ladson-Billings \& D. Gillborn (Eds.), The RoutledgeFalmer reader in multicultural education (pp. 35-48). New York: RoutledgeFalmer.

Giroux, H. A. (1999). Rethinking cultural politics and radical pedagogy in the work of Antonio Gramsci. Educational Theory, 49(1), 1-19.

Giroux, H. A. (2001). Theory and resistance in education: Towards a pedagogy for the opposition. Westport, CT: Bergin \& Garvey.

Grant, C. A., \& Ladson-Billings, G. (Eds.). (1997). Dictionary of multicultural education. Phoenix, AR: Oryx.

Greene, M. (1978). Landscapes of learning. New York: Teachers College Press.

Guy, T. C. (1999). Culture as context for adult education: The need for culturally relevant adult education. In T. C. Guy (Ed.), Providing culturally relevant education: A challenge for the twenty-first century (pp. 5-18). San Francisco, CA: Jossey-Bass.

Hall, S. (1993). Cultural studies and its theoretical legacies. In S. During (Ed.), The cultural studies reader (2 ${ }^{\text {nd }}$ ed., pp. 97-109). New York: Routledge. 
Hall, S. (1995). New ethnicities. In B. Ashcroft, G. Griffiths \& H. Tiffin (Eds.), The postcolonial studies reader (pp. 223-227). New York: Routledge.

Hall, S. (1996a). Introduction: Who needs 'Identity"? In S. Hall \& P. du Gay (Eds.), Questions of cultural identity (pp. 1-17). London: Sage.

Hall, S. (1996b). Minimal selves, In H. A. Baker Jr., M. Diawara, \& R. H. Lindeborg (Eds.), Black British cultural studies (pp. 114 - 119). Chicago: The University of Chicago Press.

Hopkins, R. (1997). Educating Black males: Critical lessons in schooling, community, and power. Albany, NY: State University of New York Press.

Hudson River Centre for Program Development. (1993). Exercise: Benefits for body and mind. Teaching guide. Health promotion for adult literacy students: An empowering approach. Glenmont N. Y. ERIC document number: ED 362758.

James, C. E., \& Brathwaite, K. (1996). The education of African Canadians: Issues, contexts, and expectations. In K. S. Brathwaite, \& C. E. James (Eds.), Educating African Canadians (pp. 13-31). Toronto, ON: James Lorimer.

Johnson, K. (1998). Notes on pan. Trinidad and Tobago Carnival [Special Expanded Issue]. The Drama Review. 42(3) (T 159), 61-73.

Jones, A. M. (1982). Steelpan: The Winston 'Spree' Simon Story (Rev. ed.). Trinidad \& Tobago: A. M. Jones.

Jones, S. H. (2005). Autoethnography: Making the personal political. In N. K. Denzin \& Y. S. Lincoln, (Eds.), Handbook of qualitative research ( $3^{\text {rd }}$ ed., pp. 763-791). Thousand Oaks: Sage.

Kachur, J. L. (1999). Privatizing public choice: The rise of charter schooling in Alberta. In T. W. Harrison \& J. L. Kachur (Eds.), Contested classrooms: Education, globalization and democracy in Alberta. Edmonton, AB: The University of Alberta Press and Parkland Institute.

Kellner, D. (1995). Media culture: Cultural studies, identity and politics between the modern and the postmodern. New York: Routledge.

King, J. E. (2004). Dysconscious racism: Ideology, identity, and the miseducation of teachers. In G. Ladson-Billings \& D. Gillborn (Eds.), The RoutledgeFalmer reader in multicultural education (pp. 71-83). New York: RoutledgeFalmer

Ladson-Billings, G. (1994). The dreamkeepers: Successful teachers of African American children. San Francisco: Josey-Bass.

Ladson-Billings, G. (1996). Lifting as we climb: The womanist tradition in multicultural education. In J. A. Banks (Ed.), Multicultural education, transformative knowledge, and action (pp. 179-200). New York: Teachers College Press.

Ladson-Billings, G. (2004). Critical race theory. In B. Ladson-Billings \& D. Gillborn (Eds.), The RoutledgeFalmer reader in multicultural education. New York: RoultedgeFalmer.

Lovelace, E. (1998). The emancipation-jouvay tradition and the almost loss of pan. [Trinidad and Tobago Carnival: Special Expanded Issue]. The Drama Review, 42(3), 54-60.

Mahoney, J. (2005, October 15). BN Story: At N.S. school, pride is coloured black. The Globe and Mail. $\quad$ Retrieved October 15, 2005, from $<$ http://www.theglobeandmail.com/servlet/story/RTGAM.20051015.wxblack-school15/

Martin, C. (1998). Trinidad Carnival glossary. [Trinidad and Tobago Carnival: Special Expanded Issue]. The Drama Review, 42(3), 220-235.

McLaren, P. (2003). Life in schools. An introduction to critical pedagogy in the foundations of education ( $4^{\text {th }}$ ed.). Toronto: Allyn and Bacon. 
Narayan, K., \& George, K. M. (2003). Personal and folk narrative as cultural representation. In J. A. Holstein \& J. F. Gubrium (Eds.), Inside interviewing: New lenses, new concerns (pp. 449-465). Thousand Oaks: Sage.

Narayan, U. (1997). Dislocating cultures: Identities, traditions, and third-world feminism. New York: Routledge.

Naylor, L. (1998). American Culture: Myth and reality of a culture of diversity. Westport: CO: Bergin \& Garvey.

Ogbu, J. U. (1991). Immigrant and involuntary minorities in comparative perspective. In M. A. Gibson \& J. U. Ogbu (Eds.), Minority status and schooling: a comparative study of immigrant and involuntary minorities (pp. 3-33). New York: Garland Publishing, Inc.

Ogbu, J. U. (1992). Adaptation to minority status and impact on school success. Theory Into Practice, XXXI (4), 287-295.

Peterson, E. A. (1999). Creating a culturally relevant dialogue for African American adult educators. In T. C. Guy (Ed.), Providing culturally relevant adult education: A challenge for the twenty-first century (pp. 79-91). San Francisco, CA: Jossey-Bass Publishers.

Reddock, R. E. (1994). Women, labour and politics in Trinidad and Tobago: A history. New Jersey: Zed Books.

Sealey, J., \& Malm, K. (1982). Music of the Caribbean. Toronto: Hodder and Stoughton.

Sewell, T. (2004). Loose canons: Exploding the myth of the 'black macho' lad. In G. LadsonBillings \& D. Gillborn (Eds.), The RoutledgeFalmer reader in multicultural education (pp. 103-116). New York: RoutledgeFalmer.

Sleeter, C. (1996). Multicultural education as a social movement. Theory into Practice, 35(4), 239-247.

Sleeter, C. E. (2002). State curriculum standards and the shaping of student consciousness. Social Justice, 29(4), 8-25.

Sleeter, C. E. (2004). How white teachers construct race. In G. Ladson-Billings \& D. Gillborn (Eds.), The RoutledgeFalmer reader in multicultural education (pp. 168-178). New York: RoutledgeFalmer.

Solomon, R. P. (1992). Black resistance in high school: Forging a separatist culture. Albany, NY: State University of New York Press.

Tedlock, B. (2005). The observation of participation and the emergence of public ethnography. In N. K. Denzin \& Y. S. Lincoln, (Eds.), Handbook of qualitative research ( $3^{\text {rd }}$ ed., pp. 467-482). Thousand Oaks: Sage.

Torres, L. (1991). The construction of the self in U.S. Latina autobiographies. In C. T. Mohanty, A. Russo \& L. Torres (Eds.), Third world women and the politics of feminism (pp. 271-287). Indianapolis, IN: Indiana University Press.

Trueba, E. T. \& Zou, Y. (1998). Introduction. In Y. Zou. \& E. T. Trueba. (Eds.), Ethnic identity and power: Cultural contexts of political action in schools and society (pp. 1-25). Albany, NY: State University of New York Press.

Walrond-Patterson, J. T. (1999). Caribbean-Canadians celebrate Carnival: Costumes and intergenerational relationships. Unpublished master's thesis, University of Alberta, Edmonton, AB, Canada.

Wang, H. (2004). The call from the stranger on a journey home: Curriculum in a third space. New York: Peter Lang.

Youdell, D. (2004). Identity traps or how Black students fail: The interactions between biographical sub-cultural and learner identities. In G. Ladson-Billings \& D. Gillborn 
(Eds.), The RoutledgeFalmer reader in multicultural education (pp. 84-102). New York: RoutledgeFalmer.

Young, I. M. (2000). Five faces of oppression. In M. Adams, W. J. Blumenfeld, R. Castañeda, H. W. Hackman, M. L. Peters \& X. Zúñiga (Eds.), Readings for diversity and social justice (pp. 35-49). New York: Routledge. 


\section{Glossary}

${ }^{1}$ Steelpan - This is a single unit of a steelband. See note 6 .

${ }^{2}$ Panorama is a competition in Trinidad where the nation's steelpan bands vie annually for prizes and the accolade as the best steelpan band.

${ }^{3}$ Dysconscious racism - is defined as "a form of racism that tacitly accepts dominant White norms and privileges. It is not the absence of consciousness (i.e. not unconsciousness) but an impaired consciousness or distorted way of thinking about race as compared to, for example, critical consciousness" (King, 2004, p. 73).

${ }^{4}$ Ethnicity - "The term ethnicity acknowledges the place of history, language and culture in the construction of subjectivity and identity, as well as the fact that all discourse is placed, positioned, situated and all knowledge is contextual" (Hall, 1995, p. 226).

${ }^{5}$ Pan yard or panyard- "The practice area and home ground of a steelband" (p. 231).

${ }^{6}$ Steel band or steelband - "A musical ensemble whose members play on instruments entirely constructed from steel drums" (p. 233).

${ }^{7}$ Badjohns - "Street-toughened fighters connected to communities and steelbands, who aggressively defend territory, dignity, and honor" (p.221). 